\title{
THE MEANING OF WORK, ORGANIZATIONAL SOCIALIZATION AND WORK CONTEXT: THE PERSPECTIVE OF MIGRANT WORKERS
}

\author{
LIDIANE CÁSSIA COMIN ${ }^{1}$ \\ https://orcid.org/0000-0003-1082-7864 \\ JANDIR PAULI ${ }^{2}$ \\ (iD) https://orcid.org/0000-0003-4618-6958
}

To cite this paper: Comin, L. C., \& Pauli, J. (2018). The meaning of work, organizational socialization and work context: The perspective of migrant workers. Revista de Administração Mackenzie, 19(spe). doi:10.1590/1678-6971/eRAMD180088

Submission: Apr. 30, 2018. Acceptance: Jul. 16, 2018.

1 Faculdade e Escola (FAT), Estação, RS, Brazil.

2 Faculdade Meridional de Passo Fundo (IMED), Passo Fundo, RS, Brazil.

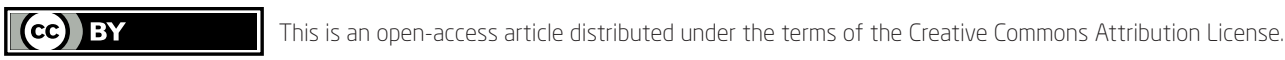

This paper may be copied, distributed, displayed, transmitted or adapted if provided, in a clear and explicit way, the name of the journal, the edition, the year and the pages on which the paper was originally published, but not suggesting that RAM endorses paper reuse. This licensing term should be made explicit in cases of reuse or distribution to third parties. It is not allowed the use for commercial purposes.

Este artigo pode ser copiado, distribuído, exibido, transmitido ou adaptado desde que citados, de forma clara e explícita, o nome da revista, a edição, o ano e as páginas nas quais o artigo foi publicado originalmente, mas sem sugerir que a RAM endosse a reutilização do artigo. Esse termo de licenciamento deve ser explicitado para os casos de reutilização ou distribuição para terceiros. Não é permitido o uso para fins comerciais. 


\section{ABSTRACT}

Purpose: The aim of this study is to analyze the relationship between meaning of work and organizational socialization labor context for migrant workers evaluation.

Originality/value: Due to the increasing number of world migrations, there is a need for research on migrants and their relation to the variables that involve organizational practices. The perception of work for migrant workers refers to the characteristics of the tasks and the way work is organized and the integration and adaptation of the individual to the environment, contributing to the attribution of meaning to work.

Design/methodology/approach: A quantitative survey was conducted by applying a questionnaire to Senegalese, Bengalese and Haitian workers who recently arrived in Brazil.

Findings: The results show the variables that lead migrants to give meaning to their work, as well as their perception about the socialization process and the context conditions. It was also demonstrated that organizational socialization partially mediates the relation between meaning of work and the perception of precarious work context for these workers. The results contribute to demonstrate the importance of organizational socialization in labor contexts that absorb migrant workers, as well as the relationship between the elaboration of the meaning of work and the perception of precarious work.

\section{KEYWORDS}

Meaning of work. Organizational socialization. Context of work. Migration. Precariousness. 


\section{INTRODUCTION}

The work represents one of the main categories of interaction between man and his social environment, seen not only as a means of survival, but also as a form of professional and personal fulfillment (Morin, 2001). The idea of centrality of work activity, shared by several authors (Borges, 2001; Morin, 2001; Vecchio, 1987), shows that people organize themselves from their professional activities, with work being the main regulator of social activities. Thus, we highlight the understanding of the concept of centrality of work activity in the life of individuals, by the reference of identity and by their contribution to the process of insertion and adaptation in an organizational context.

Workers perceive their work by the choices, experiences and environments in which they work and live (Vecchio, 1987), and they identify with it. Through the process of adaptation and learning, the individual ceases to be an external element and becomes an active and effective member of an organization (Griffin, Colella, \& Goparaju, 2001). Understanding the meaning of the new work for an individual who is in the process of integration but is marked by different cultural and behavioral issues can generate significant results for the organization (Morin, 2004).

The subjective meaning of work can vary in different contexts (Peiró \& Prieto, 1996), which makes research that considers the characteristics of each social reality relevant. When entering an organization, an individual goes through several experiences that lead him to the knowledge of this organization. Workers develop common beliefs, principles and understandings (Van Maanen \& Schein, 1979), and the organization adjusts these individual behaviors to the needs, culture and corporate values through the process called socialization (Ashforth, Sluss, \& Saks, 2007).

For this study, the discussion about the meaning of work acquires specific contours when the work is developed by migrants. Migration in search of work is an important feature of contemporary professional relationships. Migration flows in search of work have intensified, creating an environment in which borders between countries disappear. Its main motivations are related to technological advances, rapid economic growth and the internationalization of productive activities, constituting a contemporary phenomenon of great complexity (Portes, 2003).

The scenario of Brazilian immigration is characterized by the entry of people from countries such as Senegal, Ghana and Haiti, in addition to 
countries that are in situations of conflicts and wars, like Lebanon, Syria and Arabia. This migratory flow, with Brazil as its destination, reflects the barriers of immigrants to entry in European countries and in the United States (Baeninger \& Peres, 2017), as well as migration flows being in possible crisis (Clochard, 2007). Another factor to consider is the popularization of Brazil as a welcoming country with job offers, thus facilitating the entry and stay of immigrants (Almeida, 2018).

In view of the increasing number of migrations worldwide, the need for research on migrants and their relation to the variables that involve organizational practices, especially socialization, emerges. Recent studies show that the literature on the subject has largely ignored the process of socialization of migrants (Malik \& Manroop, 2015), making it necessary to elaborate studies on specific socialization tactics for new immigrants to promote their adaptation to organizations (Malik \& Manroop, 2017). This finding seems to find support in the conclusions of different recent studies that demonstrate the negative effects of a fragile or inadequate organizational socialization, especially in relation to the social identity of the migrants, contributing to the weakening of their chance to remain in the organization when socialization is not oriented to new challenges (Malik, Cooper-Thomas, \& Zikic, 2014; Shou, 2018). In general, studies indicate the need to create a cultural intelligence on the part of the organization that is able to define adequate organizational socialization strategies that recognize models of integration and performance of immigrants' roles. There is a need for organizational competences related to evaluation that identify qualified migrants, and an attempt to insert migrants into functions corresponding to their qualification (Zikic, 2015).

Studies have also have shown the occurrence of verbal, attitudinal and professional aggressions among different ethnic groups of migrant workers, due to organizational communication failures (Shenoy-Packer, 2015), as well as the partial insertion of these workers in the face of unfavorable organizational conditions to adjust the specificity of the work-family relationship of immigrants (Bonizzoni, 2014).

The relationship between organizational socialization and meaning of work was addressed in a recent study of poor migrant workers living in Israel (Sigad, Eisikovits, Strier, \& Buchbinder, 2018). Combining phenomenological and constructivist approaches, research has shown that migrants attach crucial importance to work, and this is the primary channel of socialization and insertion into local culture (Sigad, Eisikovits, Strier, \& Buchbinder, 2018). And considering that work is a channel of socialization 
in the face of uprooting caused by migration, the study also warns about the vulnerability of these workers to discriminatory practices in organizations.

Considering that the construction of the meaning of work is linked to the characteristics of the tasks and to the way work is organized, the integration and adaptation of the individual to the environment, this study aims to interpret the perception of migrant workers on the meaning attributed by them to work. What is the meaning of the work for these migrants in the labor contexts in which they are inserted? How do they perceive work and their integration in the different work environments?

In this way, the understanding of the relation between the attribution of meaning and the form of socialization of the individuals is sought, making it possible the individual perception of a context affected by the transformations of the labor world. Thus, this study contributes to analyze how workers subjectify their work experience, contributing to a more interactive view between the perceptions of the migrants and the peculiarities of each work context.

The theoretical framework proposes a situation in which organizational socialization has a mediating role in the relation between the meaning of work and the perception of working conditions. Subsequently, the methodological procedures of the research are presented through a quantitative approach. Finally, the results of the research and the final considerations are presented and analyzed.

\section{MEANING OF WORK AND ORGANIZATIONAL SOCIALIZATION}

The meaning of work assumes the instrumental character of an economic dimension, providing people with the basic necessities of survival. However, as a non-economic dimension, it provides satisfaction, relationships, occupation and utility (Morin, 2001). Discussions of the meaning of work address its significance beyond its economic link (Brief \& Nord, 1990). Seen from the perspective of its instrumental function, work is a means to an end, being central to other social systems. Already from a psychodynamic perspective, it is understood as subjective productions or products of interactions of the individual's desires with reality (Bendassolli, Coelho-Lima, Pinheiro, \& Siqueira, 2015). The meaning of work includes the characteristics that people associate with it, such as direction, purpose and coherence between each other and work (Rosso, Dekas, \& Wrzesniewski, 2010). 
The initial studies on the theme of the meaning of work were done by Hackman and Oldham (1975), focusing on the study of quality of life. For the authors, the meaning of work is perceived by the individual for its utility and legitimacy, influencing the motivation, satisfaction and productivity of the professional. In studying the meanings of work, Morin (2001) affirms that the individual is the main agent of the relationship between man and work. According to the author, in a work organization, where the objectives are clear and meaningful, the results can be expected to be positive and efficient. In this approach, the author establishes the relationship between the meaning of work and the principles of the company, as a way for the organization to rethink and reorganize the work, improving the organizational effectiveness from the individual perceptions taken to the collective.

From the positive perception of work, the individual develops physical and psychological well-being in relation to their activities, which directly impacts their commitment and their performance (Morin, 2004). Thus, according to the author, meaningful and well-conducted work makes clear and objective the achievement of organizational results, since it stimulates the team's competencies and meaning of responsibility. Socialization allows professionals from the same activity to share skills and gain recognition from others who perform the same function (Dubar, 2012).

Thus, the adaptation of the individual to the organization, to the exercised function and the group is highlighted, in which the process of inserting the individual into a profession encompasses a set of values, competences, norms (Borges \& Albuquerque, 2014), which allow them the feeling of belonging to the organization (Van Maanen and Schein, 1979). Thus, it is possible to reduce the level of anxiety and uncertainty of the new member, and to promote the alignment of their characteristics to the organization's, leading to more effective responses.

The process of interaction is constituted by pre-existing rules that are external to the individual, which regulate the social construction of reality (Berger \& Luckman, 1996). Therefore, the problems of understanding and interpreting culture and organizations are essential elements for the formulation of strategies (Bowditch \& Buono, 1992). The individuals transform themselves according to their lived experiences, in different contexts, influenced by historical, social and material conditions (Nkomo \& Cox Júnior, 1997). Through the process of socialization, people develop their identity and insert themselves into society, so it is understood that socialization makes the individual an active being in the social process, making him or her belong to the objective world and incorporating into that the subjectivity of this world (Martin-Baró, 1992). 
The main reason for the development of an organizational socialization process is based on the result of the work with higher productivity and lower costs, especially when the socialization mechanisms are fomented by the managers (Lee, Hampton, \& Jeyacheya, 2015). Organizational socialization is the process by which individuals become part of an organization (Anderson, Riddle, \& Martin, 1999). Due to the constant changes in the work context that result from productive restructuring, mobility of people and cultural diversity, organizations are required to more closely plan the process of integration, adaptation and acculturation of workers.

Despite the advances made in research on the socialization topic, literature remains fragmented (Bauer, Bodner, Erdogan, Truxillo, \& Tucker, 2007). The field has imported theories established by other thematic areas, such as those of organizational behavior (Ashford \& Nurmohamed, 2012). Haueter, Macan, and Winter (2003) deal with organizational socialization from three dimensions or domains relating to organization, work group and tasks. The authors consider that socialization does not only result in the concrete knowledge of the organization, the work group and the tasks, but the adjustment of the individual and his/her understanding of how to behave in each of these dimensions. Individuals perceive their socialization in the organization, in function of the knowledge of mission, values, strategy and culture of the organization; knowledge of the tasks and responsibilities to be performed; the acquisition of the skills necessary for the performance of their duties; and the development of interpersonal relationships with bosses and colleagues.

\section{WORK CONTEXT TRANSFORMATIONS}

The work practice, over time, continues to be represented as a necessary factor for accessing personal dignity, social prestige and citizenship. It is linked to the category of work with the cultural and moral codes of society, in order to understand the processes that are beyond the reality of work, and how it can mobilize cultural differences (Assusa, 2014). On the other hand, the work organization, centered on effectiveness based on several forms of regulation, aims to aggregate value to the company and not to the individual, making management a means for individuals to adapt to economic interests, leading individualism to rule on the capacity of collective mobilization (Rohm \& Lopez, 2015).

The moral regulation of labor was built by the logic of the market, imposed in its economic dynamics, and as a consequence of labor, the 
remuneration for the activity developed (Braga, 2012). However, the global market system gave rise to a global class structure, which divided the salaried class into two groups: wage-earning and non-wage-earning groups (Standing, 2015), thereby changing the characteristics of labor relations and legitimating inequalities promoted by labor differences.

These inequalities give rise to what literature considers as precarious work, such as informalization, precariousness, contractualization, flexibility, among other words (Arnold \& Han Shih, 2010; Maiti, 2013). For Standing (2015), there is a new class of people that does not have the minimum of trust between the capital and state relationship, called "precarious". In this context, the precarious includes work in the informal sector, including street vendors, domestic workers, teleworkers, waste pickers, small-scale farmers, artisans and migrant workers (Standing, 2008).

The mobility of a portion of workers, motivated by the achievement of a new work space and higher income, intensifies irregular and often clandestine movements, such as migrants. It exposes them to situations of vulnerability, from the border walls they find, to the anti-immigration policies of the host countries (Lima \& Junior, 2018). Thus, due to ignorance of language, illegality, lack of recognition of qualifications and discrimination, migrants are prone to take on purely instrumental activities, with no opportunity for career progression. Activities marked by low productivity and low income to achieve survival, force them into informal work, often by subcontracting or illegal use of forms of work, to avoid taxes, social contributions and regulatory guarantees (Arnold \& Bongiovi, 2013).

In this context, there is a weakening of the work that has been treated, based on the concept of precariousness, as such. The institutionalization of work flexibility is justified by the adaptation to new forms of global management. However, it ends up associating its content with precariousness, generated by the condition of instability and insecurity, arising from the collective fragmentation of work (Druck, 2011).

Precarious work is studied in a similar way to flexible and informal work. It is associated with an uncertain, low-income remuneration activity with limited social rights and benefits, being shaped by the dimensions of the insecure labor market, by the social context, by the interaction of social relations, such as gender, and by legal and political categories (Vosko, 2010). Precarious work directly or indirectly affects all dimensions of society, but especially the most vulnerable individuals, who are most likely to be in precarious employment, such as females, racial or ethnic minorities or migrants, as demonstrated by several studies (Creese, 2007; Fuller \& 
Vosko, 2008; Lima \& Junior, 2018; Noack \& Vosko, 2012; Teelucksing \& Galabuzi, 2005).

Often, work is a temporary position for migrants, resulting in greater geographic mobility and the possibility of being available for unpredictable and flexible jobs, selling their workforce and contributing to the status of illegality. Thus, the perception of the migrants of the conditions of the work context in which they are inserted is approached; the evaluation of their working conditions, verifying the precariousness regarding the lack of quality in the physical environment, in the workstation, in equipment and materials provided for the work execution; the socio-professional relations, analyzing the lack of support in the labor relations, such as difficulties in management and communication, lack of professional support of managers and colleagues; the organization of the work, trying to understand the perception of the work regarding rigidity in the division of tasks, norms, controls and work rhythms.

\section{THEORETICAL MODEL}

For this study, it was decided to test the relationships between the defined theoretical constructs, based on the research conducted by Morin (2003), Mendes and Ferreira (2008) and Haueter, Macan, and Winter (2003), making it possible to determine the relations of variables studied, as shown in Figure 4.1.

\section{(Figure 4.1)}

\section{PROPOSED THEORETICAL MODEL}

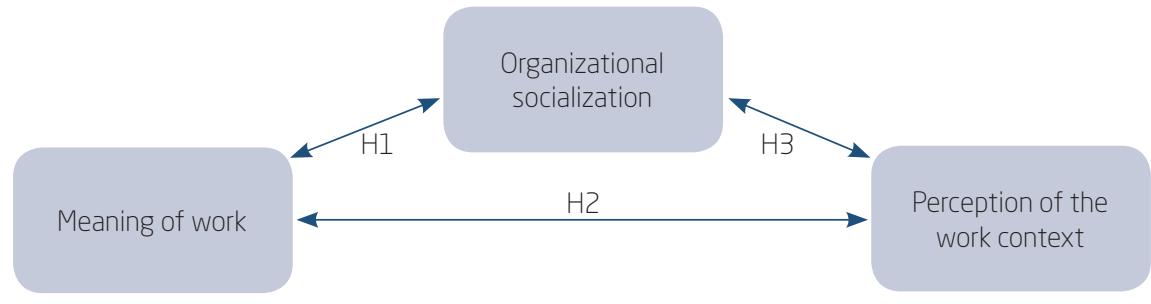

Source: Elaborated by the authors.

Career and professional status are references to individuals (Motta \& Freitas, 2000), but work continues as a structuring of people's identity and socialization (Cattani, 2000). When entering a new organization, learning 
and adjustment issues become important for new workers (Klein \& Weaver, 2000; Van Maanen \& Schein, 1979), because of their expectation of the role they will play in the group. Therefore, an organization, when developing a socialization process in an effective way, can generate positive effects for the workers (Morrison, 1993; Saks \& Ashforth, 1996), who begin to react positively to the work, since they give meaning to what they do.

Knowledge of the organization, their task and the group to which they belong will be crucial for the adaptation of individuals and directly influences their reactions and the subsequent results (Bauer, Bodner, Erdogan, Truxillo, \& Tucker, 2007; Kammeyer-Mueller \& Wanberg 2003). The understanding of norms, organizational values and work functions facilitates the newcomer to the process of insertion and adaptation in the organization.

Thus, a positive relationship is sought between organizational socialization and work in reference to the individual's adaptation to the organization, his/her group and the task to be performed, signaling to greater satisfaction and commitment (Haueter, Macan, \& Winter, 2003). It is understood, therefore, that the process of organizational socialization can contribute, in a strategic way, to increase the perception of meaningful work, since the individuals attribute meaning and meaning from their experiences (Kramer, 2010).

Considering that organizational socialization contributes to giving more meaning to work and to evaluating the relationship between the meaning of work and the organizational socialization of migrants, it is proposed that: There is a positive and significant relationship between the meaning of work and organizational socialization for migrants.

In drawing meaning from work, people consider not only the guarantee of a salary, but also that a job that generates efficient results, contributing to the moral and ethical society development. Therefore, for individuals who give meaning to their work, the work should be carried out in a safe and fair environment that promotes respect among people and considers the rules and duties of this relationship (Morin, 2001).

Management approaches are often reworked by the organization of work, in an attempt to introduce new forms of labor management from a participatory model, but the conception of the worker as a simple production resource still remains. It seeks to change attitudes and behaviors, but the order to maintain the status quo of the division of labor remains (Araújo \& Sachuk, 2007). The reconfiguration of the forms of work, as a way of managing this force favors the contribution of the conditions of economic survival, but most fail to consider the identity and the meaning attributed to 
it. Thus, new ways for capital to guarantee its profitability in the labor-capital relation emerge, significantly altering the meanings attributed to labor, affected mainly by the conditions of the labor context. For the above, it is considered that there is a direct relationship between the meaning of work and the perception of a work context as inadequate or precarious, proposing the following hypothesis: The meaning attributed to the work has a positive and significant relationship in the perception of the precarious work environment by the migrants.

In the process of socialization, work is one of the most significant elements contributing to the insertion and adaptation of the individual in society. The organizational context and environmental factors are related to the learning of a new job, and socialization strategies and practices have beneficial effects for the adaptation of a newcomer (Morrison \& Brantner, 1992).

In the relationship between giving meaning and making room for working conditions favorable to the development of meaningful work, organizational socialization is a management practice that provides the training of efficient, committed and adjusted employees to the organization, contributing to an efficient result. An effective socialization process can generate positive effects for the employees of an organization on job satisfaction and commitment (Morrison, 1993; Saks \& Ashforth, 1996), provoking a positive perception of work and feelings of satisfaction, safety, autonomy and achievement.

Organizational socialization (forms of adaptation of the individual to the organization) shows a mediating role in explaining that the relation between the meaning of work and the perception of the work context as precarious can be differentiated from its inference. In this context, it is understood that the socialization process can influence or modify the relationship between the meaning of work and the perception of the work context as precarious or not, according to the intensity and the way the process is conducted by the organizations. Thus, the following hypothesis is formulated: Organizational socialization acts as a mediating variable in the relationship between the meaning of work and the perception of the context of precarious work by the migrants.

\section{METHODOLOGICAL PROCEDURES}

The present study is classified as a descriptive field survey, quantitative in nature, through a survey. The purpose of this study was to analyze the 
relationship between the meaning of work, the organizational socialization and the perception of precarious work context for migrant individuals.

The study population comprises migrant individuals, and as delimitation, Haitian, Senegalese, Bangladeshi and Ghanaian migrants, identified in a larger number in the region where the survey was conducted, were sampled for this study. The selection of the research sample was made for convenience, following the pre-established criteria: be a Haitian, Senegalese or Bengali migrant; reside and work in a company with a formal contract of employment; be over 18 years old; be male or female; and have entered the country after 2009.

The final sample consisted of 186 respondents, $93 \%$ of whom were male. The predominance of the respondents comprising the age group between 21 and 30 years $(67.6 \%)$ corresponded to a young public, of working age who were mostly single $(65.1 \%)$. As for nationality, the majority were Senegalese $(73.7 \%)$, followed by Haitians $(18.3 \%)$, with a minority of Ghanaians and Bangladeshi $(8.1 \%)$.

For the collection of primary data, a questionnaire composed of closed-ended, single-choice questions was used, in the form of affirmations, within a degree of disagreement or agreement, by a five-point Likert scale, being: from $1=$ totally disagree, to $5=$ totally agree.

The questionnaire was applied personally to the participants of the selected sample, individually and also in small groups. In the case of the migrants who presented difficulties of interpretation due to a poor understanding of the Portuguese language, a colleague of the same nationality of the respondent assisted them in reading the questions, translating them into the respondent's native language.

The research instrument of the present study was elaborated with a set of questions, dealing with organizational socialization, meaning of work and conditions of the work context. The elaboration of the questions was adapted from the following instruments: Scale of Work Context Evaluation (SWCE) (Mendes \& Ferreira, 2008), Meaning of Work Scale (MWS) (Morin, 2003) and Newcomer Socialization Questionnaire (NSQ) (Haueter, Macan, $\&$ Winter, 2003), with adaptations made by the authors, in order to meet the linguistic and cultural peculiarities of migrant workers, thus respecting the sensitivity of scale measurement by respondents (Tourangeau \& Rasinski, 1988).

As a way of verifying the degree of understanding of the statements, at the end of each construct, a question was included as a control. The migrant gave his/her answer directly to what the construct was intended to measure. 
The questions were: does my job have meaning to me? Do I evaluate my work as precarious? Do I consider myself socialized in the company in which I work? In the analysis of the data, these questions were compared with the final average of the constructs for the verification of the answers' understanding.

Before the data collection, a pre-test was applied to a group of 19 respondents, aiming at the complete understanding of the questionnaire, according to the adaptation of the original scales, as well as to verify the necessary response time. The questionnaire was also presented to a bank of technical professionals in order to validate their adaptation according to content.

The technique was applied was the multivariate analysis of data, especially factorial analysis and multiple linear regression. This technique allows the adoption of statistical methods to measure the variables simultaneously, exploring the relationship between them (Hair Jr., Babin, Money, \& Samouel, 2005). The linear regression techniques and the procedures described by Preacher and Hayes (2004) and Zhao, Lynch Jr. and Chen (2010) were used for the mediation relation tests between the variables, with the aid of the SPSS macro, MODPROBE developed by Hayes \& Matthes (2009).

\section{RESULTS}

In order to understand what makes it possible to "extract" meaning from the work for the migrants surveyed, 19 variables were investigated, according to a questionnaire adapted from Morin (2003), through the means of the answers obtained in the research, referring to the construct meaning of work. The descriptive statistics of the variables show that the items of the meaning-of-work construct had an average ranging from 2.7 to 4.19. For the understanding of organizational socialization the averages varied between 3.08 and 4.24, and for the evaluation of the work context, the variation was between 3.05 and 3.73. These responses show that the higher the average, the greater the meaning attributed to work, the greater the socialization, and the greater the perception of the work context as precarious for the migrants surveyed.

Adequacy statistics of the sample showed favorable results. For the data collected in this sample, the Cronbach's alpha presented a high reliability of the scales $(0.891)$, the Bartlett sphericity test was significant $(p<0.001)$ 
and the KMO showed adequacy with an index of 0.764 . In relation to the association of variables, the correlation matrix (Figure 6.1) shows that the association between the meaning of work, organizational socialization and perception of the precarious work context occurs in a significant, positive and moderate way, showing that the individuals' perceptions evolve in the same direction. It can therefore be stated that the more meaningful the work is attributed by the migrant, the greater they perceive a precarious work context $(\mathrm{r}=0.543, \mathrm{p}<0.001)$. In addition, as organizational socialization increases, the meaning of the work for these individuals increases too $(r=0.522, p<0.001)$. As for the organizational socialization related to the perception of the precarious work context, it is noticed that there is a positive relation $(\mathrm{r}=0.408, \mathrm{p}<0.001)$.

The exploratory factor analysis allowed verification of the grouping of the variables of the research, according to the proposed dimension. The results showed this grouping through 12 factors, which explain $69.84 \%$ of the data variance, with factorial loads above 0.4 (Hair Jr., Babin, Money, \& Samouel, 2005) and communalities above 0.50 (Malhotra, 2012).

\section{(Figure 6.1)}

PEARSON CORRELATIONS OF CONTRUCTIONS IN STUDY

\begin{tabular}{|c|c|c|c|}
\hline \multicolumn{4}{|c|}{ Correlations } \\
\hline & $\begin{array}{c}\text { Precarious work } \\
\text { context }\end{array}$ & $\begin{array}{l}\text { Organizational } \\
\text { socialization }\end{array}$ & $\begin{array}{l}\text { Meaning of } \\
\text { work }\end{array}$ \\
\hline Precarious work context & 1 & & \\
\hline Organizational socialization & $0.408^{\star \star}$ & 1 & \\
\hline Meaning of work & $0.543^{\star \star}$ & $0.522^{\star \star}$ & 1 \\
\hline
\end{tabular}

** Significance level $p<0.001$.

Source: Elaborated by the authors.

In order to test the relationships between the research variables, multiple regression analysis techniques were used, with their adjusted $\mathrm{R}^{2}$ values, $\mathrm{F}$ value and the $95 \%$ confidence interval for the dimensions analyzed, which are presented in Figure 6.2. 


\section{(Figure 6.2)}

RELATIONS BETWEEN MEANING OF WORK, THE ORGANIZATIONAL SOCIALIZATION AND PRECARIOUS WORK CONTEXT

\begin{tabular}{ccccccc}
\hline \multirow{2}{*}{ Model } & \multicolumn{3}{c}{ Organizational socialization } & \multicolumn{3}{c}{ Perception of the Work Context } \\
\cline { 2 - 7 } & Beta & $\mathrm{R}^{2}$ Adjusted & $\mathrm{F}$ & Beta & $\mathrm{R}^{2}$ Adjusted & $\mathrm{F}$ \\
\hline Meaning of Work & $0.522^{* \star}$ & 0.268 & 53.222 & $0.543^{* *}$ & 0.290 & 60.919 \\
\hline
\end{tabular}

** Significance level $p<0.001$.

The initial hypothesis $(\mathrm{H} 1)$ of this study predicted a positive relationship between the meaning of work and organizational socialization, the results pointed to statistical support. The results found in the model show that the meaning of the work has a positive and significant relationship with organizational socialization ( $\beta=0.522, p<0.001)$, explaining $26.8 \%$ of this relation $\left(\mathrm{R}^{2}=0.268\right)$. It is possible, therefore, to affirm that the hypothesis 1 is totally accepted by the relation established between these two variables: the more meaning migrants attribute to their work, the greater their socialization with the organization.

When assigning meaning to work, the individual expresses his/her identification by the exercise of his/her functions (Morin, 2001). Organizational identity is influenced by personal identity, attributing to this identity a new meaning, arising from the relationships that are developed in the organizational environment (Araújo \& Sachuk, 2007).

Corroborating with Kramer's (2010) propositions, individuals attribute meaning and meaning to their experiences, and the process of organizational socialization can contribute strategically to the perception of meaningful work. By effectively developing a socialization process, positive effects can be generated for workers (Morrisson, 1993; Saks \& Ashfotth, 1996), because of the meaning they attribute to what they do. In this process, the learning and the adjustment issues of workers become essential to the achievement of their expectations, regarding the role they will play in the new group (Klein \& Weaver, 2000; Van Maannen \& Schein, 1979). These expectations, when they are met, stimulate the competencies of the professionals in that they feel part of the process and are committed to the collective activity of the organization, in a way that improves the quality of life and organizational effectiveness (Morin, 2001) of the group and the company.

The second hypothesis (H2) indicates that the meaning of work has a positive and significant effect on the perception of the work context as 
precarious by the migrants. The regression matrix presented in Figure 6.2 shows that the meaning of the work explains $29 \%\left(\mathrm{R}^{2}=0.290\right)$ of the perception of the work context by the migrants, presenting a positive and significant relation in the tested model $(\beta=0.543, \mathrm{p}<0.001)$, supporting the study in $\mathrm{H} 2$. This confirmation corroborates with the theoretical propositions that suggest the precariousness of the work by the objective and subjective dimension. The objective dimension is defined by low remuneration, physical and psychological risks, lack of opportunity for development, and the subjective dimension by the dissatisfaction of the conditions of insecurity generated by the uncertain employment, absence of protection and low levels of qualification (Kalleberg, 2009). Labor management implies providing safe and healthy working conditions through ethical behaviors that stimulate workers' effectiveness (Morin, 2004), since the meaning of work influences forms of work activity and worker productivity (Vecchio, 1987).

Based on the results obtained, the perception of work context by the migrants is influenced not only by the instrumental dimension of the work, but also by the subjective meaning of these migrants in the interaction with the social environment in which they are inserted. These results corroborate with Morin's (2003) studies in which work as a moral medium plays an important role in society, being prescribed as correct, accepted by the community and seen as a sign of appreciation for what the individual does, expressing, thus, the situation of being precariousness or not.

In order to confirm the theoretical findings, according to what organizational socialization seeks to adapt individuals to the organizational context in order to improve their linkage through concrete knowledge of the organization, the work group and the tasks it performs (Hauter, Mancan, \& Winter, 2003), the objective was to analyze the third hypothesis (H3) of this study, which predicted organizational socialization as a mediator of the relationship between the meaning of work and the perception of the context of precarious work by migrants.

When testing the indirect relation of the meaning of work in the perception of the precarious work context, mediated by the socialization, the mediation tests were applied, according to Zhao, Lynch Jr. \& Chen (2010), calculated by the bootstrap procedure for 5,000 samplings, including zero for a $95 \%$ confidence interval.

As shown in Figure 6.3, the meaning of work has a positive and significant effect on organizational socialization $(a=0.540, p<0.001)$, as organizational socialization has a positive and significant effect in the 
context of precarious work $(b=0.205, \mathrm{p}<0.05)$. Similarly, the meaning of the work has a positive and significant effect on the context of precarious work $(c=0.545, p<0.001)$. The indirect effect of the meaning of work in the perception of the precarious work context, through organizational socialization, was also positive and significant ( $\mathrm{x} \mathrm{b}=0.112, \mathrm{p}<0.05)$, with a significant and positive value also in the total effect $(c '=0.656$, $\mathrm{p}<0.001)$.

Considering the significant direct effect, it can be said that the process of organizational socialization mediates, in a partial way, the relation between the meaning of work and the perception of the precarious work context for the researched migrants, that is, organizational socialization indirectly influences the perceived precariousness of the work context, given the meaning attributed by migrants to their work. This fact can also be called complementary mediation (Basso, 2012), indicating the possibility of other factors that also interfere in this mediating relationship. However, they were not measured in this study model, highlighting the importance of this consideration for the breadth of organizational studies and the different interferences of individuals' behaviors that may occur in the organizational context.

These results provide support for the confirmation of hypothesis 3 of this study, evidencing the mediating role of socialization in the perception of precarious work context, through the meaning attributed to work by migrants, suggesting that other organizational processes or practices can mediate this relation to make it complete.

In this case, this explanation is also possible through the understanding of the concept of socialization through different perspectives (Morrison, 1993), for example, the social identification process or also the tactics and strategies of adaptation and learning of the individual in the organization. These factors were not contemplated in this study, which considered the perception of the migrant worker on the organization, its intragroup relations and the tasks performed. 


\section{(Figure 6.3)}

\section{MEDIATING EFFECT OF ORGANIZATIONAL SOCIALIZATION}

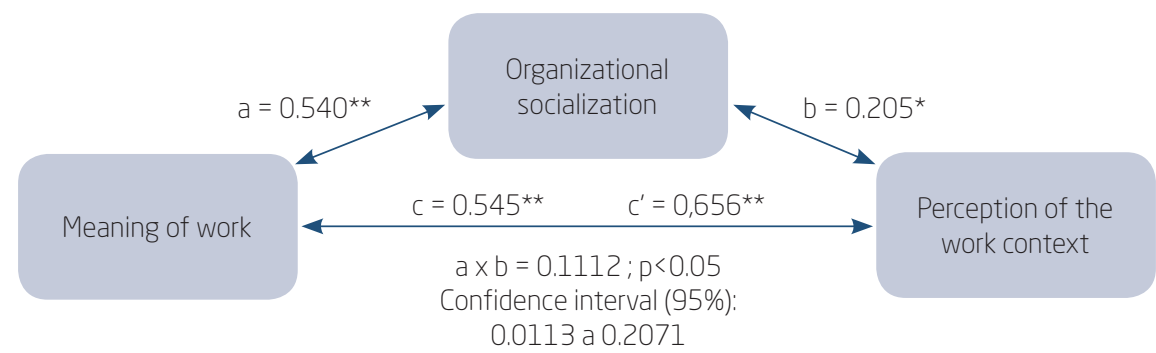

* Significance level $p<0.001$

* Significance level $p<0.05$

Source: Elaborated by the authors.

The process of socialization through work enables people to adapt better, not only in the organizational context but also in society, allowing the construction of reality (Berger \& Luckman, 1966), especially for individuals who migrate from a culture that is very different from the local culture, as is the case of the migrants studied.

Through the relationship of mediation, it is concluded that socialization influences the perception of the work context as precarious, due to the value attributed by migrants to their work. That is, there is an effect of the process of adaptation of migrants, in the organizational context, which makes the perceptions of working conditions change, contributing to the discussion of the importance of the socialization role of individuals in relation to the meanings attributed to their work.

\section{DISCUSSION}

In order to broaden the knowledge about organizational behavior, this study analyzed the relationship between meaning of work, organizational socialization and work context in the perception of migrants.

Based on the theoretical model proposed in this study, a greater understanding of the variables that lead migrants to assign meaning to their work in the context of the conditions in which they perform their tasks was demonstrated, showing that organizational socialization can generate a mediating effect on this relationship. 
Thus, in response to the question and the objectives of this research, Figure 7.1 summarizes the results found when testing the proposed model.

(Figure 7.1)

SUMMARY OF RESEARCH RESULTS

$\mathrm{HI}$ - There is a positive and significant relationship between the meaning of

Confirmed

work and organizational socialization for migrants.

$\mathrm{H} 2$ - The meaning attributed to the work has a positive and significant

Confirmed

relationship in the perception of the precarious work environment by the

migrants.

H3 - Organizational socialization acts as a mediating variable in the relation

Confirmed

between the meaning of work and the perception of the context of precarious

work by the migrants.

Source: Elaborated by the authors.

The work represents, in society, a means of giving meaning to life (Emmons, 2005; Steger, Dik, \& Duffy, 2012). For the migrants surveyed, this meaning is translated by the necessary conditions for life made possible through work, being the source of identity, opportunity, achievement, occupation and morality, showing that the individual is inserted within a community and performs roles accepted by the community. Thus, it is confirmed in this study that, in addition to the economic dimension, work for migrants connects with the feeling of pleasure, fulfillment and relationships with other people of their conviviality and colleagues, as a form of affiliation to their groups.

The attribution of meaning to work, and the adaptation of migrants to work, refers them to the process of adaptation in the social environment, in search of socialization. Socialization can be defined as the process of adaptation of the individual in the organization, the way in which he/she performs tasks and his/her behavior in the group, evaluating what is considered appropriate for that context (Anderson, 2006; Hauter, Mancan, \& Winter, 2003). In this vision, it was realized that the migrants surveyed seek to socialize within their companies, knowing and adapting to the new jobs. When arriving at companies, the degree of uncertainty about the unknown place creates even more obstacles within the structure and the work context, so they seek to know their tasks and to understand quickly how to execute them.

The data analyzed show that the perception of the context of precarious work for migrants is influenced by the meaning attributed to their work. 
Therefore, the perception of a precarious working environment for migrant individuals has a direct relationship with the way work structures their lives, economic stability and, above all, the moral relations they establish with society. Likewise, the results show that this meaning attributed to work contributes to organizational socialization, directly interfering with the perception of the conditions of the work context.

These results reinforce the theoretical assumptions that work promotes relations of exchange with the environment through dynamic behaviors that are capable of transforming the characteristics of the individual and influencing their perception in relation to the work context. Yet, they confirm that by sharing values, beliefs and habits, individuals make themselves principles that guide their actions (Fernandes \& Zanelli, 2006).

The performance of human capital has been increasingly seen as a critical factor in organizational survival and sustainability. Faced with a new generation of the workforce, which includes migrant labor, the commitment and engagement of employees can be better understood through meaningful work that provides appropriate conditions for their development. The meaning of work is influenced by the organization of the work, which is capable of changing the behavior of the workers, in a positive way, in their functions (Morin, 2001). Through organizational practices, it is possible to better train and manage this workforce, promoting inter-relationships actions and facilitating their adaptation process.

From the proposed theoretical model, there was a greater understanding of the variables that lead migrants to assign meaning to their work in the face of the perception of the context conditions in which they perform their tasks, demonstrating that organizational socialization can generate a mediating effect on this relationship. Socialization is a continuous process of learning (Ostroff \& Kozloniski, 1992), and this becomes a relevant factor when, in this study, the relationship found is that, for migrants with more company time, socialization explains the relationship with the perception of labor precariousness. This is because, over time, migrants acquire more information and knowledge about tasks, their role in the group and, consequently, in the organization.

The results analyzed confirm the mediating effect of socialization, which reinforces that the theme cannot be seen in a fragmented way, but in conjunction with other themes related to organizational behavior (Asfhord $\&$ Nurmohamed, 2012), as organizational practices aimed at organization from the individual roles (Van Maanen \& Schein, 1979).

In fact, it is important to consider not only the socio-cultural peculiarities of the subjects of this research, including the change in climate from their 
original home, as well as their status as political refugees, but also the centrality that the work acquires in their life, since they are willing to move to another country in search of a job. It is in this context that the results contribute to understanding the first objective of this research, which was to analyze the relationship between the meaning of work and organizational socialization. Moreover, the confirmation of the influence of meaning on the perception of precarious work, as well as the mediating role of socialization, allow us to postulate the importance of the working environment in the social life of migrant workers. It reinforces the idea of work as a privileged locus of meaning and socialization in the face of the typical adversities and labor discontinuities to which these workers are subject.

\section{FINAL CONSIDERATIONS}

The analysis of the results obtained allows us to conclude that meaningful work is related to other subjective factors, such as the adaptation of the individual in a context, as well as their perception about this context. These factors are highly related to meaningful work that, according to data from this study, not only give sustenance, but also accomplish, satisfy and motivate the subject to perform the work, and make him/her an active participant in a group.

Considering the implications of this study, the meaning of the work for the migrants surveyed is directly related to work organization, which is capable of changing the behavior of workers in a positive way in their functions. Thus, studies such as this on the meaning of work can contribute to the development actions of new members in the organization, generating greater commitment to the company values, and a strategic alignment of organizational and individual objectives, promoting a conductive work environment to reach these goals.

Regarding the managerial implications of the study, the results point to the need to consider the meanings attributed to work by migrant workers, in order to rethink how organizational socialization practices are being implemented by managers in face of the cultural diversity that exists in their companies.

As a measure of research, it was noted in the course of the study that organizational socialization is a very broad construct, which can be interpreted in several ways. Thus, when considering other measures of socialization, approaching variables different from those worked, other 
research may find different results in the relationship between the meaning of work and the perceptions about the work context, as well as in different contexts and other service sectors.

This deepening is also relevant through qualitative studies, using techniques that allow the expression of individuals, thus providing a broader interpretation of the richness and diversity explained by the migrants on the different themes of the research, such as their experiences, the influence of cultural variables of their countries of origin and the plurality of differences between their countries of origin and destination.

\section{SENTIDOS DO TRABALHO, SOCIALIZAÇÃO ORGANIZACIONAL E CONTEXTO LABORAL: A PERSPECTIVA DOS TRABALHADORES MIGRANTES}

\section{RESUMO}

Objetivo: O objetivo deste estudo é analisar a relação entre sentido do trabalho, socialização organizacional e avaliação do contexto laboral para trabalhadores migrantes.

Originalidade/relevância: Pelo número crescente das migrações mundiais, emerge a necessidade de pesquisas sobre o migrante e sua relação com as variáveis que envolvem as práticas organizacionais. A percepção do trabalho para trabalhadores migrantes, remete às características das tarefas e à forma como se organiza o trabalho, a integração e a adaptação do indivíduo ao meio, contribuindo para a atribuição de sentido ao trabalho. Principais aspectos metodológicos: Foi realizada uma pesquisa quantitativa de tipo survey, através da aplicação de um questionário a trabalhadores senegaleses, bengaleses e haitianos recentemente chegados ao Brasil. Síntese dos principais resultados: Os resultados evidenciam as variáveis que levam o migrante a atribuir sentido a seu trabalho, bem como sua percepção sobre o processo de socialização e as condições do contexto. Demonstrou-se, também, que a socialização organizacional media, parcialmente, a relação entre sentido do trabalho e percepção de contexto de trabalho precários para esses trabalhadores. Os resultados contribuem para demonstrar a importância da socialização organizacional em contextos laborais que absorvem trabalhadores migrantes, bem como a 
relação entre a elaboração do sentido do trabalho e a percepção de trabalho precário.

\section{PALAVRAS-CHAVE}

Sentido do trabalho. Socialização organizacional. Contexto de trabalho. Migração. Precarização.

\section{REFERENCES}

Almeida, C. D. (2018). Migração e trabalho: Relatos de haitianos em São Paulo. Revista de Ciências Humanas e Sociais, 4(1), 14-28.

Anderson, C. M., Riddle, B. L., \& Martin, M. M. (1999). Socialization processes in groups. In L. R. Frey, D. S. Gournan, \& M. S. Poole (Eds.), The Handbook of Group Communication: Theory and Research (pp. 139-163). Thousand Oaks, CA: Sage.

Araújo, R. R., \& Sachuk, M. I. (2007). Os sentidos do trabalho e suas implicações na formação dos indivíduos inseridos nas organizações contemporâneas. Revista de Gestão, 14(1), 53-66.

Arnold, D., Han Shih, T. (2010). A fair model of globalisation? Labour and global production in Cambodia. Journal of Contemporary Asia, 40(3), 401424. doi:10.1080/00472331003798376

Arnold, D., Bongiovi, J. R. (2013). Precarious, informalizing, and flexible work: Transforming concepts and understandings. American Behavioral Scientist, 57(3), 289-308. doi:10.1177/0002764212466239

Ashforth, B. E., Sluss, D. M., \& Saks, A. M. (2007). Socialization tactics, proactive behavior, and newcomer learning: Integrating socialization models. Journal of Vocational Behavior, 70(3), 447-462. doi:10.1016/j. jvb.2007.02.001

Ashford, S., \& Nurmohamed, S. (2012). From past to present and into the future: A Hitchhiker's guide to the socialization literature. The Oxford Handbook of Organizational Socialization, 1-20. doi:10.1093/oxfordhb/97 80199763672.013.0002

Assusa, G. (2014). Trabajo y moralidade en las relaciones de producción capitalistas. Sociologias, 16(36), 180-205. doi:10.1590/15174522-016003612 
Baeninger, R., \& Peres, R. (2017). Migração de crise: a migração haitiana para o Brasil. Revista Brasileira de Estudos Populacionais, 34(1), 119-143. doi:10.20947/S0102-3098a0017

Basso, K. (2012). Violação e recuperação da confiança do cliente após o duplo desvio (Unpublished doctoral dissertation). Universidade Federal do Rio Grande do Sul, Rio Grande do Sul, RS.

Bauer, T. N., Bodner, T., Erdogan, B., Truxillo, D. M., \& Tucker, J. S. (2007). Newcomer adjustment during organizational socialization: a meta-analytic review of antecedents, outcomes, and methods. Journal of Applied Psychology, 92 (3), 707-721. doi:10.1037/0021-9010.92.3.707

Bendassolli, P. F., Coelho-Lima, F., Pinheiro, R. de A.; Gê, P. C. de S. (2015). The Brazilian scientific production on sense and meaning of work: Review of use of terminology and current thematic classifications. Avances en Psicología Latinoamericana, 33 (2), 203-221. doi:10.12804/ap133.02.2015.03

Berger, P. L., \& Luckmann, T. (1996). The social construction of reality. Garden City, NY: Doubleday.

Bonizzoni, P. (2014). Immigrant working mothers reconciling work and childcare: The experience of Latin American and Eastern European women in Milan. Social Politics, 21 (2), 194-217. doi:10.1093/sp/jxu008

Borges, L. O. (2001). Crenças do trabalho: Diferenças entre acadêmicos e dirigentes de empresas. Revista Psicologia Organizações e Trabalho, 1 (1), 43-67.

Borges, L. O., Albuquerque, F. J. B. (2014). Socialização Organizacional. In J. C. Zanelli, J. E. Borges-Andrade, \& A. V. B. Bastos. Psicologia, organizações e trabalho no Brasil (2nd ed., pp. 351-384). Porto Alegre, RS: Artmed.

Bowditch, J. L., \& Buono, A. F. (1992). Elementos de comportamento organizacional. São Paulo, SP: Pioneira.

Brief, A. P., \& Nord, W. R. (1990). Meanings of occupational work: A collection of essays. Toronto, ON: Lexington Books.

Cattani, A. D. (2000). Trabalho e autonomia. Petrópolis, RJ: Vozes.

Chou, S. Y. (2018). A theoretical analysis of immigrant employees' organizational citizenship behaviors in organizations. Journal of Global Mobility: The Home of Expatriate Management Research, 6(2), 209-225. doi:10. 1108?JGI01-2018-0004

Clochard, O. (2007). Les réfugiés dans le monde entre protection et illégalité. EchoGéo, 2, 1-10.

Creese, G. (2007). Racializing work/reproducing white privilege. In V. Shalla (Org.), Work in tumultuous times: Critical Perspectives (pp. 192-226). Montreal, QB: McGill-Queen's University Press. 
Druck, G. (2011). Trabalho, precarização e resistências: Novos e velhos desafios. Caderno CRH, 24(1), 37-57. doi:10.1590/S0103-497920110004 00004

Dubar, C. (2012). A construção de si pela atividade de trabalho: A socializaçao profissional. Cadernos de Pesquisa, 42(146), 351-367. doi:10.1590/S0 100-15742012000200003.

Fernandes, K. R., \& Zanelli, J. C. (2006). O processo de construção e reconstrução das identidades dos indivíduos nas organizações. Revista de Administração Contemporânea, 10(1), 55-72. doi:10.1590/S1415-65552006000 100004.

Fuller, S., \& Vosko, L. F. (2008). Temporary employment and social inequality in Canada: Exploring intersections of gender, race and immigration status. Social Indicators Research, 88(1), 31-50. doi:10.1007/s11205-0079201-8

González, P., Peiró, J. M., \& Bravo, M. J. (1996). Calidad de vida laboral. In J. M. Peiró \& F. Prieto (Eds.), Tratado de psicología del trabajo: Volumen II. Aspectos Psicosociales del Trabajo (pp. 161-186). Madrid, MD: Síntesis.

Griffin, A. E. C., Colella, A., \& Goparaju, S. (2001). Newcomer and organizational socialization tactics: An interactionist perspective. Human Resource Management Review, 10(4), 453-474.

Hackman, J. R., \& Oldham, G. R. (1975). Development of the job diagnostic survey. Journal of Applied Psychology, 60 (2), 159-170. doi:10.1037/h0076546

Hair Jr., J. F., Babin, B., Money, A. H., \& Samouel, P. (2005). Fundamentos de métodos de pesquisa em administração. Porto Alegre, RS: Bookman.

Hauter, J. A., Macan, T. H., Winter, J. (2003). Measurement of newcomer socialization: Construct validation of a multidimensional scale. Journal of Vocational Behavior, 63 (1), 20-39. doi:10.1016/S0001-8791(02)00017-9

Hayes, A. F., \& Matthes, J. (2009). Computational procedures for probing interactions in OLS and logistic regression: SPSS and SAS implementations. Behavior Research Methods, 41 (3), 924-936. doi:10.3758/BRM.41.3.924

Instituto Brasileiro de Geografia e Estatística. Censo Demográfico de 2010. Retrieved from http://www.ibge.gov.br/home/estatistica/populacao/ censo2010/

Kalleberg, A. L. (2009). Precarious work, insecure workers: Employment relations in transition. American Sociological Review, 74(1), 1-22. doi:10.117 7/000312240907400101 
Kammeyer-Mueller, J. D., \& Wanberg, C. R. (2003). Unwrapping the organizational entry process: Disentangling multiple antecedents and their pathways to adjustment. Journal of Applied Psychology, 88(5), 779-794. doi:10.1037/0021-9010.88.5.779

Klein, H. J., \& Weaver, N. A. (2000). The effectiveness of an organizationallevel orientation training program in the socialization of new hires. Personnel Psychology, 53(1), 47-66. doi:10.1111/j.1744-6570.2000.tb00193.x

Kramer, M. W. (2010). Organizational socialization: Joining and leaving organizations. Cambridge, GB: Polity.

Lee, D., Hampton, M., \& Jeyacheya, J. (2015). The political economy of precarious work in the tourism industry in small island developing states. Review of International Political Economy, 22 (1), 194-223. doi:10.1080/0969 2290.2014.887590

Lima, J. C., \& Martins Junior, A. (2018). Mobilidades diferenciadas e ilegalidades isntitucionalizadas: Tendências e contradições do trabalho na contemporaneidade. Tempo Social, 30(1), 31-51. doi:10.11606/0103-2070. ts.2018.138076

Maiti, D. (2013). Precarious work in India trends and emerging issues. American Behavioral Scientist, 57(4), 507-530. doi:10.1177/0002764212 466247

Malhotra, N. K. (2012). Pesquisa de marketing: Uma orientação aplicada (6th ed.). Porto Alegre, RS: Bookman.

Malik, A. R., Cooper-Thomas, H. D., \& Zikic, J. (2014). The neglected role of cultural intelligence in recent immigrant newcomers' socialization. International Journal of Cross Cultural Management, 14(2), 195-213. doi:10.11 77/1470595813507245

Malik, A., \& Manroop, L. (2017). Recent immigrant newcomers' socialization in the workplace: Roles of organizational socialization tactics and newcomer strategies. Equality, Diversity and Inclusion: An International Journal, 36(5), 382-400. doi:10.1108/EDI-11-2016-0083

Martin-Baró, I. (1992). Los procesos de socialización. In I. Martin-Baró, Acción e ideología: Psicología social desde Centroamérica (pp. 113-180). San Salvador, SV: Uca Editores.

Mendes, A. M., \& Ferreira, M. C. (2008). Contexto de trabalho. In M. M. M. Siqueira (Org.), Medidas do comportamento organizacional: Ferramentas e diagnóstico de gestão (pp. 111-123). Porto Alegre, RS: Artmed. 
Morin, E. M. (2001). Os sentidos do trabalho. Revista de Administração de Empresas, 41 (3), 08-19. doi:10.1590/S0034-75902001000300002

Morin, E. M. (2003). Sens du travail: Définition, mesure et validation. In C. Vandenberghe, N. Delobbe, \& G. Karnas (Ed.). Dimensions individuelles et sociales de l'investissement professionnel, 2, 11-20

Morin, E. M. (2004). The meaning of work in modern times. Paper presented at the 10th World Congress On Human Resources Management. Rio de Janeiro, RJ. Retrieved from http://www.choixdecarriere.com/pdf/6573/ 2010/Morin2004.pdf

Morrison, E. W. (1993). Longitudinal study of the effects of information seeking on newcomer socialization. Journal of Applied Psychology, 78(2), 173-183. doi:10.1037/0021-9010.78.2.173

Morrison, R. F., \& Brantner, T. M. (1992). What enhances or inhibits learning a new job? A basic career issue. Journal of Applied Psychology, 77(6), 926-940. doi:10.1037/0021-9010.77.6.926

Motta, F. C. P., \& Freitas, M. E. (2000). Vida psíquica e organização. Rio de Janeiro, RJ: Editora FGV.

Vecchio, R. P. (1987). The meaning of working: Mow - International Research Team. London, UK: Academic Press.

Nkomo, S., \& Cox Júnior, T. (1997). Diversidade e identidade nas organizações. In S. R. Clegg, C. Hardy, W. R. Nord (Org.). Handbook de estudos organizacionais: Modelos de análise e novas questões em estudos organizacionais. São Paulo, SP: Atlas.

Noack, A. M., \& Vosko, L. F. (2012). Precarious jobs in Ontario: Mapping dimensions of labour market insecurity by workers' social location and context. Report prepared for the Ontario Law Commission, Vulnerable Worker Project. Toronto, ON. Retrieved from https://www.lco-cdo.org/wpcontent/uploads/2012/01/vulnerable-workers-call-for-papers-noackvosko.pdf

Oliveira, A. T. R. (2015). Migrações internacionais e políticas migratórias no Brasil. Migração e mobilidade na América do Sul. Cadernos OBMigra-Revista Migrações Internacionais, 1 (3).

Ostroff, C., Kozlowski, S. W. J. (1992). Organizational socialization as a learning process: The role of information acquisition. Personnel Psychology, 45(4), 849-874. doi:10.1111/j.1744-6570.1992.tb00971.x

Paugam, S. (2002). Le salarié de la précarité. L'orientation scolaire et professionnelle, $31(3)$. 
Portes, A. (2003). Conclusion: Theoretical convergencies and empirical evidence in the study of immigrant transnationalism. International Migration Review, 37(3), 874-892. doi:10.1111/j.1747-7379.2003.tb00161.x

Preacher, K. J., \& Hayes, A. F. (2004). SPSS and SAS procedures for estimating indirect effects in simple mediation models. Behavior Research Methods, Instruments, and Computers, 36(4), 717-731. Retrieved from http://quantpsy. org/pubs/preacher_hayes_2004.pdf

Rohm, R. H. D., \& Lopes, N. F. (2015). O novo sentido do trabalho para o sujeito pós-moderno: Uma abordagem crítica. Cadernos EBAPE, 13(2), 332-345. doi:10.1590/1679-395117179

Rosso, B. D., Dekas, K. H., \& Wrzesniewski, A. (2010). On the meaning of work: A theoretical integration and review. Research in Organizational Behavior, 30, 91-127. doi:10.1016/j.riob.2010.09.001

Saks, A. M., \& Ashforth, B. E. (1996). Proactive socialization and behavioral self-management. Journal of Vocational Behavior, 48(3), 301-323. doi:10.10 06/jvbe.1996.0026

Shenoy-Packer, S. (2015). Immigrant professionals, microaggressions, and critical sensemaking in the US workplace. Management Communication Quarterly, 29(2), 257-275. doi:10.1177/0893318914562069

Standing, G. (2008). Economic insecurity and global casualisation: threat or promise? Social Indicators Research, 88(1), 15-30. doi:10.1007/s11205-0079202-7

Standing, G. (2015). O precariado: a nova classe perigosa. Belo Horizonte, MG: Autêntica.

Steger, M. F., Dik, B. J., \& Duffy, R. D. (2012). Measuring meaningful work: The work and meaning inventory (WAMI). Journal of Career Assessment, 20, 322-337. doi:10.1177/1069072711436160

Tourangeau, R., \& Rasinski, K. A. (1998). Cognitive processes underlying context effects in attitude measurement. Psychology Bull, 103, 299-314.

Van Maanen, J., \& Schein, E. H. (1979). Toward a theory of organization socialization. Research in Organizational Behavior, 1, 209-264. Retrieved from https://dspace.mit.edu/bitstream/handle/1721.1/1934/SWP-096003581864.pdf

Vosko, L. F. (2010). Managing the margins: Gender, citizenship and the international regulation. New York: Oxford University Press.

Zhao, X., Lynch Jr., J. G., \& Chen, Q. (2010). Reconsidering Baron and Kenny: Myths and truths about mediation analysis. Journal of Consumer Research, 37(2), 197-206. doi:10.1086/651257 


\section{AUTHOR NOTES}

Lidiane Cássia Comin, Business Administration, Universidade do Oeste de Santa Catarina (UNOESC); and Jandir Pauli, Department of Sociology, Universidade Federal do Rio Grande do Sul (UFRS).

Lidiane Cássia Comin is now Business Administration Professor at Faculdade e Escola (FAT); and Jandir Pauli is now Business Administration Professor at Faculdade Meridional de Passo Fundo (IMED).

Correspondence concerning this article should be addressed to Lidiane Cássia Comin, Lido Giacomoni Street, 131, Santuário, Estação, Rio Grande do Sul, Brazil, CEP 99930-000.

E-mail: lc.comin@bol.com.br

\section{EDITORIAL BOARD}

\section{Editor-in-chief}

Silvio Popadiuk

Associated Editor

Andrea Oltramari

Technical Support

Vitória Batista Santos Silva

\section{EDITORIAL PRODUCTION}

Publishing Coordination

Irina Migliari

Language Editor

Daniel Leão

\section{Editorial Trainee}

Maria Luiza Vanz

Layout Designer

Emap

Copy Editor

Irina Migliari
Graphic Designer Libro 